\title{
Comparison between two methods of ionized calcium measurement in newborns
}

\author{
Comparação entre dois métodos de determinação de cálcio \\ ionizável em amostras de recém-nascidos
}

Thaís P. Basseto ${ }^{1}$; Ligia Ajaime Azzalis²; Edimar Cristiano Pereira ${ }^{3}$; Virginia Berlanga Campos Junqueira ${ }^{4}$;

Luciana Zambelli Caputo ${ }^{5}$; Alexandre Luiz Affonso Fonseca ${ }^{6}$; David Feder ${ }^{7}$; Fernando Luiz Affonso Fonseca ${ }^{8}$

\begin{abstract}
Changes in ionized calcium (iCa) concentration seem to occur in newborns when the calcium supply from the mother is disconnected at birth, and a related hypocalcemia is produced. Thus, measurement of iCa is of particular importance in newborns. The aim of this study was to compare two methods of iCa measurement. We collected 50 samples from newborns in which we obtained values of iCa using both the direct and the indirect measurement. There is a significant correlation between iCa values obtained from Omni $\mathrm{C}$ and those obtained from the calculated method.
\end{abstract}

Key words: calcium; human newborns; ionized calcium.

\section{INTRODUCTION}

Calcium is an essential mineral in the human body, involved in several important metabolic processes, such as blood clotting, muscle excitability and contraction, transmission of nerve impulses, enzyme activation, second messenger formation and hormone secretion, with the main feature of mineralization of bone and teeth ${ }^{(9)}$.

Calcium is present in the plasma in three forms: the free ionized calcium (iCa) constitutes about $50 \%$ of the total; $35 \%$ to $40 \%$ are bound to proteins, mainly to albumin; and $10 \%$ to $15 \%$ are complexed with low-molecular-weight ligands such as bicarbonate, phosphate, lactate, citrate, and others ${ }^{(8)}$.
Though poorly understood, the regulation of calcium homeostasis in the newborn has been of considerable interest. At birth, the iCa level in cord blood exceeds that in maternal blood. Recent findings show that parathyroid hormone-related peptide plays an important role in transferring calcium across the placenta into the fetal circulation. During the early days of life, the iCa level progressively decreases in normal infants, so that by the second or third day of life, the level is lower than that found in older infants and children. In most normal full-term infants the iCa level returns to normal by 10 days of life. In some infants the plasma iCa falls to pathologically low levels, and tetany or convulsions may occur ${ }^{(6)}$.

First submission on $05 / 01 / 13$; last submission on $05 / 01 / 13$; accepted for publication on 30/05/13; published on 20/10/13

1. Biomedical scientist; coordinator of the medical laboratory of Hospital Estadual Mário Covas.

2. Doctorate in Biochemistry from Instituto de Química da Universidade de São Paulo (IQ-USP); associate professor at Universidade Federal de São Paulo (UNIFESP), campus

Diadema.

3. Doctorate in Clinical Analysis from Faculdade de Ciências Farmacêuticas da USP (FCF-USP); associate professor at UNIFESP, campus Diadema.

4. Professor of Biochemistry at IQ-USP; full professor at UNIFESP, campus Diadema.

5. Master's degree in Pathophysiology at Faculdade de Medicina da USP (FMUSP); professor at Universidade de Santo Amaro (UNISA).

6. Master's degree in Public Health from Hospital Emílio Ribas; assistant professor at Instituto de Pesquisa e Educação em Saúde de São Paulo (IPESSP).

7. Doctorate in Internal Medicine from UNIFESP; full professor at Faculdade de Medicina do ABC (FMABC).

8. Post doctoral research in Clinical Biochemistry from Roche Center for Medical Genomics-Basel (RCMG); coordinator of the medical laboratory of FMABC; associate professor at UNIFESP, campus Diadema. 
In almost all Brazilian laboratories, only total calcium is routinely measured, and iCa concentration is indirectly calculated based on total calcium, total protein and albumin concentrations. Errors associated with the measurement of those and other variables, such as $\mathrm{pH}$, contribute to the difficulty of producing useful formulae to calculate iCa indirectly. Direct measurement of iCa by potentiometry is the method of choice for iCa determination, but it is an expensive analysis ${ }^{(8)}$. Therefore, the aim of this study was to evaluate whether iCa measured by potentiometry (direct measurement) correlates with $\mathrm{iCa}$ calculated by formulae (indirect measurement) in newborns.

\section{SUBJECTS AND METHODS}

\section{Subjects}

After parents' consent, 50 newborns underwent the protocol previously approved by the Ethics Committee. The criteria included newborns, but excluded those showing marked malnutrition, and/or premature babies. The group comprised male $(n=26)$ and female $(n=24)$ 9-day-old (mean) newborns, from NeoMater Hospital, in São Bernardo do Campo, São Paulo, Brazil.

\section{Determination of iCa}

After at least a four-hour fast, an anaerobic venous blood sample was drawn between 7 and 9 a.m. The samples were analyzed in duplicate at the hospital laboratory. The samples for albumin, total protein and total calcium were collected using gel heparin tubes. They were measured colorimetrically using Selectra II analyzer. A serum sample was taken for the direct measurement of iCa, which was carried out by potentiometry using Omni $\mathrm{C}$ apparatus.

All instruments and methods were found to be in good working order based on the manufacturer's descriptions and accumulated quality-control data. Among numerous formulae proposed to obtain serum iCa, the following formula was chosen because it is the most frequently used in Brazil ${ }^{(3)}$ :

$\mathrm{iCa}=\{6 \times$ total calcium $(\mathrm{TCa})-$ [albumin $+(0.19 \times$ total protein $) / 3]\} /$ [albumin $+(0.19 \times$ total protein $)+6]$.

\section{Statistical analysis}

The statistical differences between mean values were assessed by Student's $t$ test. The Pearson's correlation coefficient and its level of significance were calculated by the bivariate correlation procedure.

\section{RESULTS}

\section{Patients' characteristics}

The Table lists the mean values for age, both directly and indirectly measured iCa, total calcium, albumin and total protein of the newborns. All newborns were in good health.

No statistical differences were noted between directly $(1.18 \pm$ $0.16)$ and indirectly $(1.47 \pm 0.23)$ measured iCa values.

\begin{tabular}{cc}
\hline \multicolumn{2}{c}{ TABLE - Data of newborns } \\
\hline Parameters & Mean \pm SD $(n=50)$ \\
\hline Age (days) & $9.2 \pm 9.5$ \\
$\mathrm{iCa}$ - direct measurement (mmol/l) & $1.18 \pm 0.16$ \\
Total calcium (mg/dl) & $10.47 \pm 1.74$ \\
Albumin (mg/dl) & $3.374 \pm 0.351$ \\
Total protein (mg/dl) & $5.38 \pm 0.78$ \\
$\mathrm{iCa}-$ calculated $(\mathrm{mmol} / \mathrm{l})$ & $1.47 \pm 0.23$ \\
\hline
\end{tabular}

SD: standard deviation; iCa: ionized calcium.

\section{Association between directly obtained serum iCa and calculated iCa}

The Figure shows that iCa measured by potentiometry (direct measurement) correlates with iCa calculated by formulae (indirect measurement) in newborns $(r=0.609, p<0.001)$.

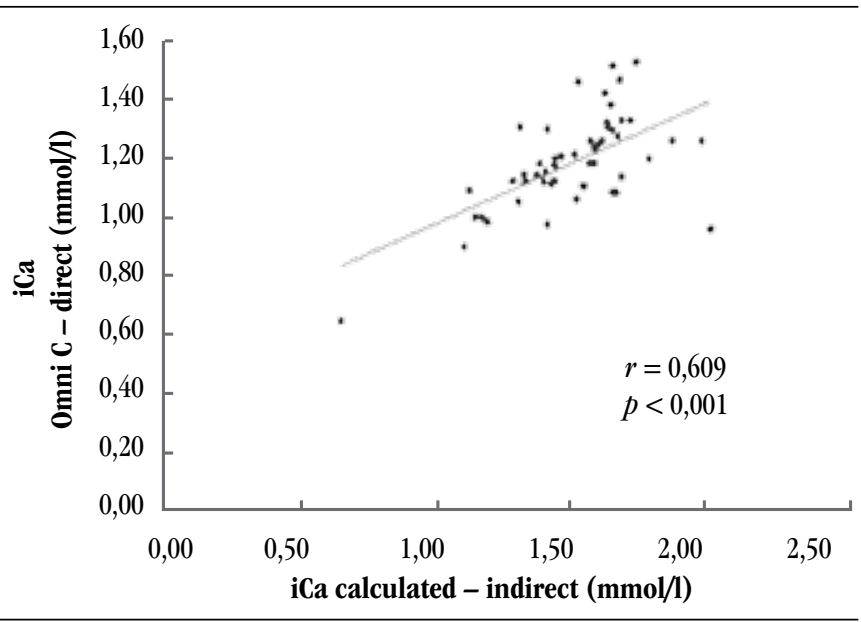

FIGURE - Pearson's correlation between ionized calcium obtained by potentiotiometry (Omni C) and obtained by formulae (calculated)

\section{DISCUSSION}

This study is important because profound changes in $\mathrm{iCa}$ concentration seem to occur in newborns when the calcium supply from the mother is removed at birth, and a related hypocalcemia is produced. Thus, there is a demand for a reliable assessment of 
iCa measurement in newborns. Moreover, it is necessary to verify if the iCa measurement obtained by potentiometry can be correlated with the iCa calculated by formulae (indirect measurement) in newborns. To our knowledge, few studies pursue those aims ${ }^{(6)}$.

Once iCa is the most important physiologic fraction of calcium, it is necessary to measure it directly or to estimate it from measurements of total calcium, total protein, and albumin. Both methods, however, have limitations that must be understood for the appropriate interpretation of iCa levels in the clinical setting ${ }^{(5)}$.

Precision in iCa measurement was revolutionized after the introduction of ion-selective electrodes; however, the clinical application of this technique was initially limited and delayed by its cost, susceptibility to errors, need to prevent $\mathrm{CO}_{2}$ losses from the sample, and control of $\mathrm{pH}^{(7)}$. Advances in technology for direct measurement of iCa have decreased the cost and improved its availability in the clinical setting since the $1980 \mathrm{~s}^{(1)}$. A number of limitations remained, however, particularly in the outpatient setting, including the technical challenge of equipment maintenance, frequent electrode replacement with associated downtime, and redundancy of instrumentation and personnel, all leading to increased costs ${ }^{(2,4)}$.

We think that iCa measurement can be systematically performed, directly or indirectly, in newborns because it was possible to verify a significant correlation between both methods. Also, our mean levels for iCa are consistent with previously published values ${ }^{(4)}$. Perhaps, in sicker newborns with malnutrition and low albumin, the calculated iCa cannot be used.

It is possible to conclude that there is a significant correlation between the iCa values obtained using Omni $\mathrm{C}$ apparatus and the calculated ones. We believe that both methods can be used in newborns.

\section{RESUMO}

As alterações na concentração de cálcio ionizado (iCa) ocorrem nos recém-nascidos quando a fonte de cálcio proveniente da mãe é removida no momento do nascimento, resultando em hipocalcemia. Portanto, a verificação de iCa é de particular importância no recém-nascido. O objetivo deste estudo foi comparar dois métodos de determinação de iCa utilizados em laboratórios. Foram utilizadas 50 amostras de recém-nascidos que obtiveram valores de iCa pela medida direta e também pelo método indireto. Existe uma correlação significativa entre os valores de iCa obtidos utilizando Omni C e aqueles com o método calculado.

Unitermos: cálcio; recém-nascidos; cálcio ionizável.

\section{REFERENCES}

1. BAIRD, G. S.; RAINEY, P. M.; WENER, M.; CHANDLER, W. Reducing routine ionized calcium measurement. Clin Chem, v. 55, n. 3, p. 533-40, 2009.

2. BJORKMAN, M. D.; SORVA, A. J.; TILVIS, R. S. Calculated serum calcium is an insufficient surrogate for measured ionized calcium.Arch Gerontol Geriatr, v. 49, n. 3, p. 348-50, 2009.

3. COSTA, M. B.; LANNA, C. M. M.; BRAGA, M. H.; MAGALHÃES, S. Avaliação da hipercalcemia assintomática em pacientes ambulatoriais [Assessment of asymptomatic hypercalcemia]. J Bras Patol Med Lab, v. 44, n. 5, p. 329-35, 2008.

4. GAUCI, M. et al. Pitfalls of measuring total blood calcium in patients with CKD. J Am Soc Nephrol, v. 19, p. 1952-8, 2008.

5. GIGENnE, S.; VIGEZZI, J. F.; DAMIANO, J.; CLERC, Y. Direct determination or estimated value of plasma ionized calcium: indications and limits. Ann Biol Clin, v. 61, n. 4, p. 393-9, 2003.

6. MITCHELL, D. M.; JUPPNER, H. Regulation of calcium homeostasis and bone metabolism in the fetus and neonate. Curr Opin Endocrinol Diabetes Obes, v. 17, n. 1, p. 25-30, 2010.

7. SEAMONDS, B.; TOWFIGHI, J.; ARVAN, D. A. Determination of ionized calcium in serum by use of an ion-selective-electrode. Clin Chem, v. 18, n. 2, p. 155-60, 2002.

8. TERTTI, R.; HARMOINEN, A.; LESKINEN, Y.; METSARINNE, K. P.; SAHA, H. Comparison of calcium phosphate product values using measurement of plasma total calcium and serum ionized calcium. Hemodialysis International, v. 11, p. 411-6, 2007.

9. ZIEGLER, O.; SIRVEAUX, M. A.; BRUNAUD, L; REIBEL, N.; QUILLIOT, D. Medical follow up after bariatric surgery: nutritional and drug issues. General recommendations for the prevention and treatment of nutritional deficiencies. Diabetes Metab, v. 35, p. 544-57, 2009.

\section{MAILING ADDRESS}

Fernando Luiz Affonso Fonseca

Laboratório de Análises Clínicas da Faculdade de Medicina do ABC; Av. Príncipe de Gales, 821; CEP: 09060-650; Santo André-SP, Brazil; e-mail: profferfonseca@gmail.com. 